\title{
DIGITAL TECHNOLOGIES, LABOR MARKETS, AND ECONOMIC REPUTATION
}

\author{
George Lăzăroiu, ${ }^{1, a, *}$, Derek Rommer ${ }^{2, b}$ \\ ${ }^{1}$ Faculty of Socio-Human Sciences, Spiru Haret University, Strada Ion Ghica 13, Bucharest 030045, \\ Romania \\ ${ }^{2}$ Australasian Center for Knowledge Governance, CSA, 30-18 50 ${ }^{\text {th }}$ Street, Woodside, New York City, \\ 11377, United States \\ aphd_lazaroiu@yahoo.com, brommer@aa-er.org \\ *Corresponding author
}

Cite as: Lazaroiu, G., Rommer, D. (2017). Digital technologies, labor markets, and economic reputation, Ekonomicko-manazerske spektrum, 11(2), 13-21.

Available at: dx.doi.org/10.26552/ems.2017.2.13-21

\begin{abstract}
Following Gandini (2016), this paper strives to prove that knowledge work has altered with the incorporation of digital technologies into operations of production and organization. Influenced by the boost of electronic and social media, a digital and independent knowledge economy focused on a collective, dispersed cultural idea of reputation as usefulness resulted. Imagining reputation as a type of value is the predominant elucidatory pattern of knowledge work in the digital epoch. We aim to address these increasing features by elaborating on the fact that knowledge work has altered as a consequence of the visionary assessment of inventiveness as a slogan for cutting edge and professional development. We plan to determine that reputation becomes a particular type of particularized social capital for knowledge employees. We use meta-analysis to assess evidence proving that because the social buttons managing social undertakings on digital media platforms deal with and preserve an individual's full online activity, determining it with statistics, the reputation of a distinct employee is publicly observable, concrete, obtainable, and possibly quantifiable. We inspected the Web of Science and identified 240 papers covering the impact of reputation on the socio-economic interactions in digital labor markets. We analyzed them carefully and present our conclusions, highlighting that reputation adjusts the professional market of the knowledge economy by functioning as a particular kind of capital or positive feature for people in a setting constituted of networked and recently mediatized social interplay.
\end{abstract}

Keywords: reputational, capital, digital, labor, market

JEL Classification: G18, H11, I28

\section{Introduction}

We rely on Gandini (2016, A, B) to prove that knowledge work has altered with the incorporation of digital technologies into operations of production and organization: the circumstances of continuation of current knowledge work have been impacted by the notion of resourcefulness, being entirely assimilated into a regulatory and organizational coherence of knowledge production originated in imaginativeness, generating various procedures that have altered present occupations and kinds of professional activity in diverse settings of the knowledge economy. (Gandini, 2016, A) The concepts of personal and self-branding (Machan, 2016, A) in the knowledge economy designate the mechanisms of marketization (Androniceanu 
\& Drăgulănescu, 2016, A) of the self (Weede, 2016) for the confidence-building (Coyle, 2017) and professional accomplishment of the laborer (Rickard et al., 2017). Self-branding is a type of digital labor as a financing in social connections with a required return, which indicates the obtainment of a reputation (Vong, 2017). Self-branding covers the contributing factor for fruitful job search (Androniceanu \& Drăgulănescu, 2016, B) and the creation of socialized value throughout the freelance-based labor market (Vitalari, 2016) of the digital knowledge economy. Reputation is the configuration of social capital in digitalized settings (Mohamed \& 'Ain, 2017), where social interplay frequently appears remotely and with an insignificant degree of copotentiality and closeness, being a contributory characteristic in guaranteeing recruitment in a freelance-based economy (Bauder, 2016) because it exemplifies the inherent, cultural notion of value distributed by actors in the labor market. (Gandini, 2016, B) Social media is a working device that provides the curation (Androniceanu, 2012) of a professional perception and the handling of social connections for goals of professional accomplishment and career advancement. Social media undertaking is constituted of performative routines of sociality that are extant around a mutual concept of reputation (Besciu \& Androniceanu, 2017) as the cultural notion of value (Krahe \& Campbell, 2016; da Silva \& Baroni Cecato, 2017).

\section{Literature review}

Digital technologies have considerably been incorporated into mechanisms of creation and organization (Radic, 2017), being instrumental in swiftly and effectively redesigning the operations of valorization (Nagel, 2016) in the knowledge industry in addition to the satisfying of demand and supply. Knowledge labor has been shaped by the rationales of creative work and has harmonized digital technologies into a diversity of operations, for digital and freelance personnel that configures a multi-functional professional division (Machan, 2016, B) with initial characteristics. The current socio-economic professional arena is contingent on the handling of social connections (Green, 2017) and the increase of the routes via which they are practiced, preserved, and mediated. The advance of social network sites (Ahmed, 2016) and platforms has considerably interfered within the routines and underlying forces of hiring in the industry. A surplus of websites consecrated to various types of work-related issues and niche job markets multiply on the web, having as their main business the sharing of laborers and the satisfying of various types of supply and demand (Androniceanu, 2014) on diverse job markets. (Gandini, 2016, A) Reputation economy enables the sharing out of dissimilar informational resources in the differentiated labor market (Mihăilă, 2016, B) by operating as the mediator that converts social connections into value (Hazelkorn, 1997). The digital knowledge economy is made up of diverse types of online interplay (Kirchner, 2015) that allow advanced routines of sociality contingent on notoriety (Friedman et al., 2016) and affect, which connect branding and value through a collective concept of reputation. Self-branding (Androniceanu, 2017) in the digital knowledge economy facilitates groundbreaking routines of sociality that are not restricted to the branding of the self but serve as marketing labor that associates networking with the handling of social connections. The assimilating of self-branding routine to the shaping of social capital is essential for the grasp of self-marketing (Vasile \& Androniceanu, 2016) in the digital knowledge economy. The utilization of social media assists the objective of managing the architecture of a reputation via the employment of personal branding techniques (Madsen \& Wu, 2016), allowing novel kinds of managerially driven sociality according to which digital technologies and social media enable reputation to be definite through various indicators, displaying it as the most relevant asset for the separate brand. (Gandini, 2016, B) 


\section{Methodology}

We use meta-analysis and secondary data to determine that knowledge work has altered as a consequence of the visionary assessment of inventiveness as a slogan for cutting edge and professional development, and, influenced by the boost of electronic and social media, a digital and independent knowledge economy focused on a collective, dispersed cultural idea of reputation as usefulness resulted. Then we inspected the Web of Science and identified 240 papers covering the impact of reputation on the socio-economic interactions in digital labor markets. Imagining reputation as a type of value is the predominant elucidatory pattern of knowledge work in the digital epoch. (Gandini, 2016, A) The employability of knowledge professionals in the digital epoch is connected with the obtainment of a reputational capital throughout the personal chain of professional acquaintances. Reputation is progressively definite, noticeable and assessable through the operation of separate individuals on social media platforms. The achievement of reputational capital is the central aspect for employability, because reputation is the cultural notion of value (Hurd, 2016) indigenously distributed by operators in the professional framework. Reputation links the offline and online spheres, construing self-branding as a mechanism of social capital articulation managerially designed that employs reputation to distribute disproportionate resources. (Gandini, 2016, B)

\section{Empirical data and analysis}

We analyzed and made estimations concerning the most important sectors in digital recruitment growth (increase in ads for digital roles) and as regards digital disruption (proportion of digital tech businesses in sector), and as a consequence the development of selfemployment and of temporary employment in Europe, and of agency work (worldwide). Reputation becomes a particular type of particularized social capital for knowledge employees: it is a commodity negotiated by them in a labor market where they perform as autonomous experts managing their own standing as an economic endowment, being an investment in social connections with prospects of economic earnings, and being critical for job obtainment. The function played by an individual's reputation in the knowledge economy may be a recent driver for career advance. Because the social buttons managing social undertakings on digital media platforms deal with and preserve an individual's full online activity, determining it with statistics, the reputation of a distinct employee is publicly observable, concrete, obtainable, and possibly quantifiable. (Gandini, 2016, A) The obtainment of a reputation (Hanappi et al., 2016) in the industry can be achieved through a series of routines of sociality by which the branding of an individual's professional integrity and public representation occur in a social sphere, constituted of a symbiotic link between offline and online mingling. Such periodical routines have a performative character, being expressed by a steady generation of content that assumes a notion of the digital realm as a kind of operation space for the achievement of a branded distinctiveness. Their social public self typifies a striking array of a collocation of professional abilities and personal disposition, entailing an individual's links and networks, resulting the articulation of a reputational capital, bringing about capitalization in relation to job chances and returns throughout an arrangement of social connections, constantly maintained through the utilization of shared marketing techniques, thus indicating the articulation of commitment with the self-brand to activate the constitution of links that may operate as a capital (Siekelova et al., 2017), which can be catalyzed or accessed when required. (Gandini, 2016, B) (Figures 1-8) 
Digital Technologies, Labor Markets, and Economic Reputation

Authors: George Lazaroiu, Derek Rommer

Figure 1: Top 10 sectors in digital recruitment growth

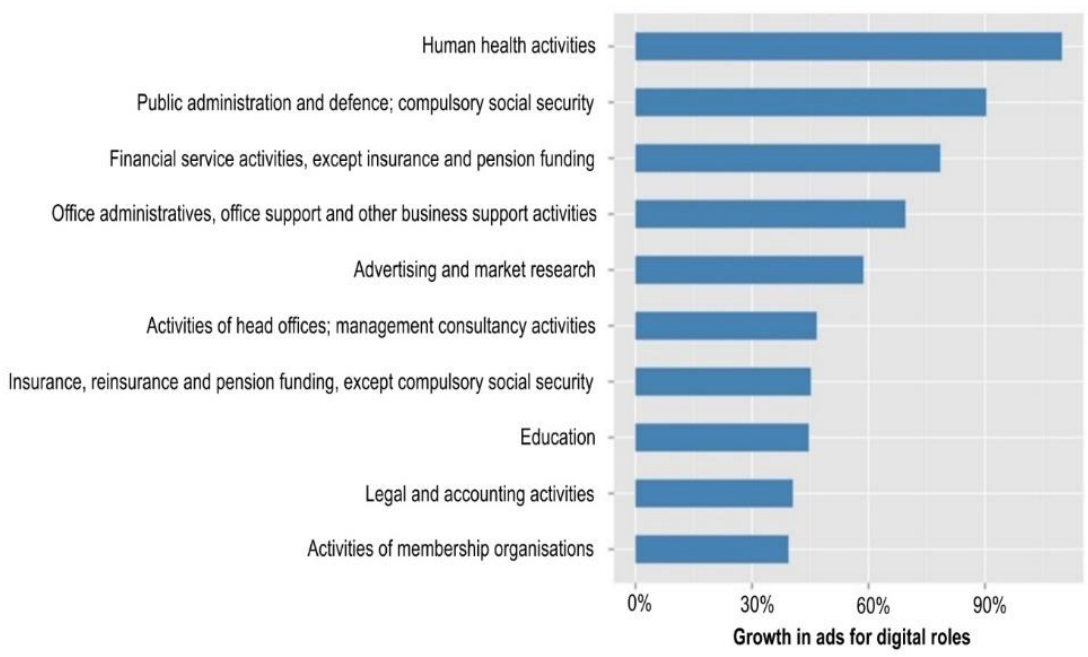

Source: Burning Glass data and Tech Nation (2016) and our estimations

Figure 2: Top 20 sectors by digital disruption (excluding digital sectors)

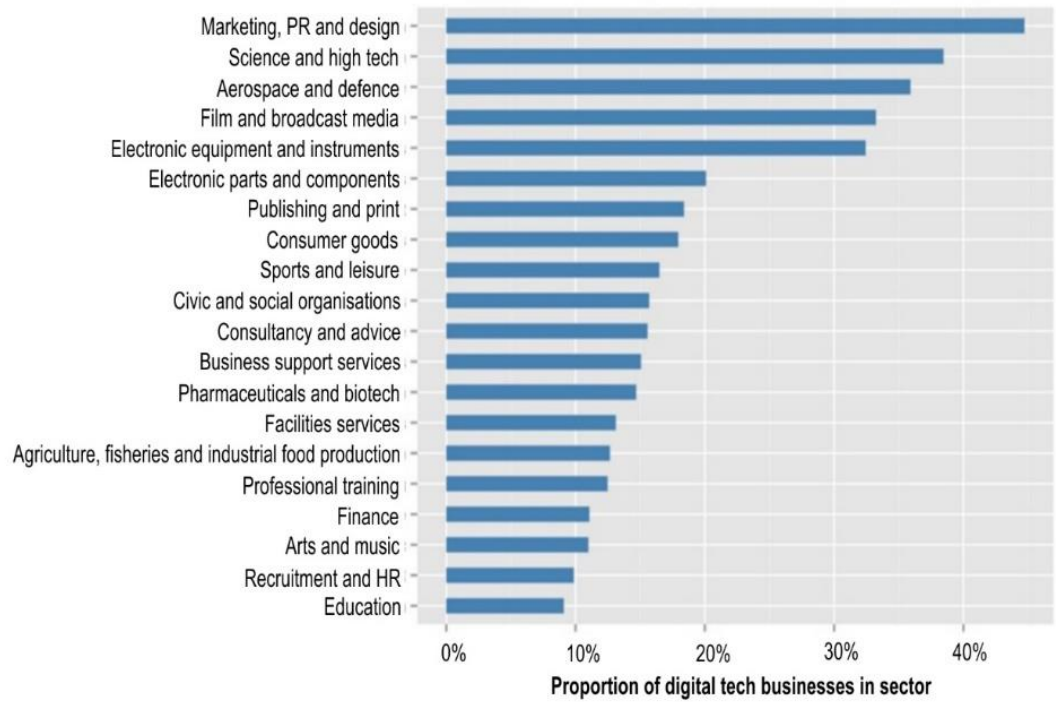

Source: GrowthIntel and Tech Nation (2016) and our estimations

Figure 3: Development of self-employment in Europe

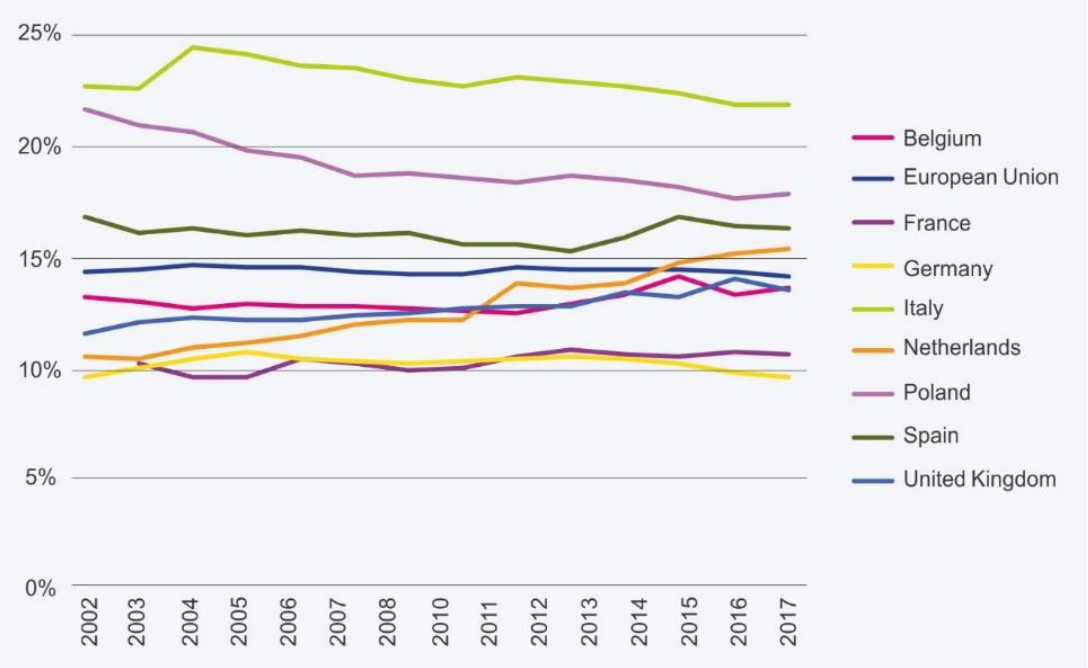

Source: Eurostat (2016) and our estimations 
Figure 4: Development of temporary employment in Europe

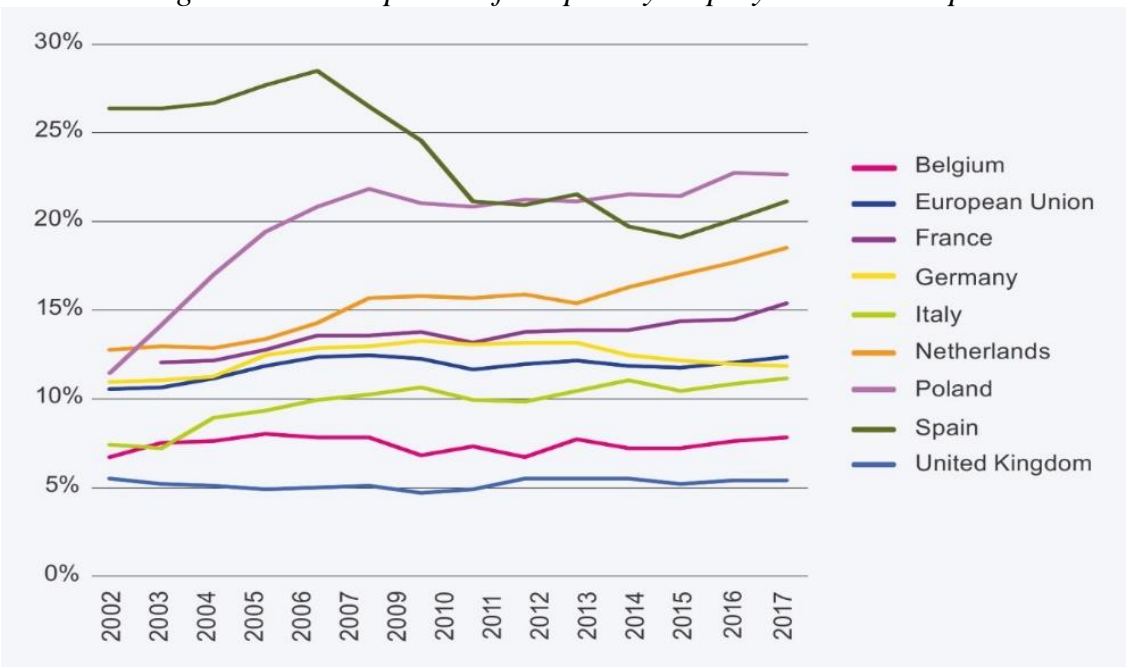

Source: Eurostat (2016) and our estimations

Figure 5: Development of agency work

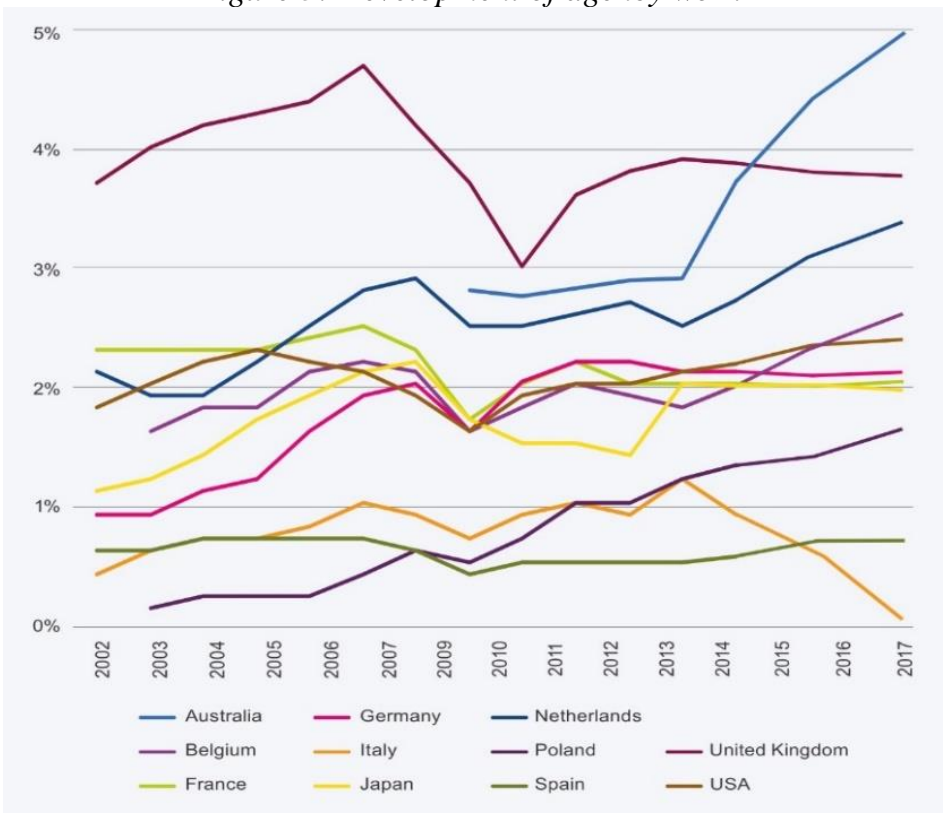

Source: Eurostat (2016) and our estimations

Figure 6: Wage growth still missing from job market recovery

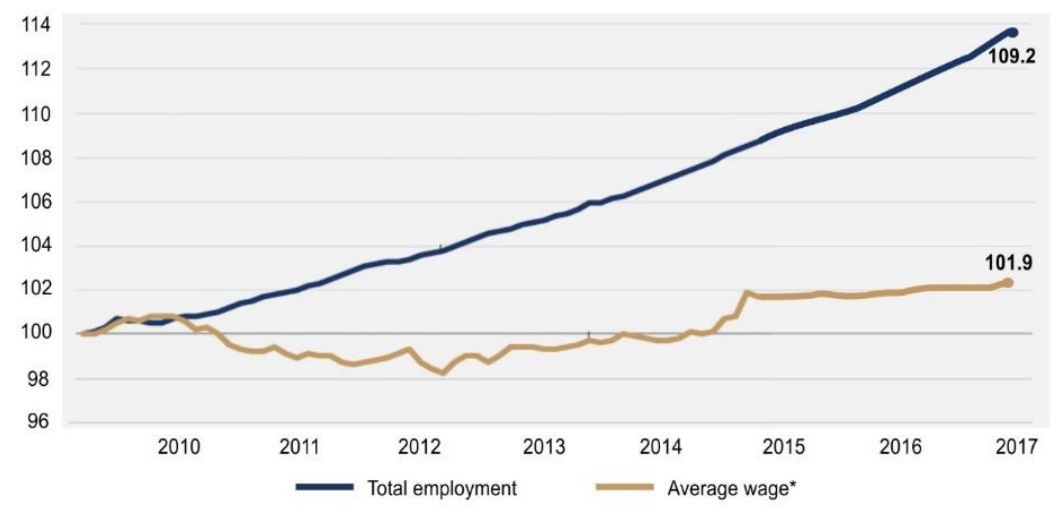

Sources: Center for American Progress analysis of Bureau of Labor Statistics data (2016) and our estimations *Average hourly earnings of production and nonsupervisory employees, adjusted for inflation 
Figure 7: Growth of knowledge-based service industries in Europe and UK (1970-2017)

EU15 share of value added

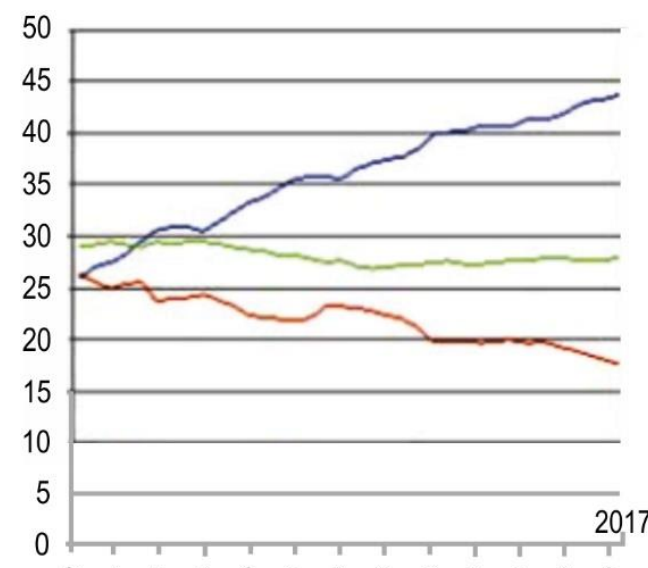

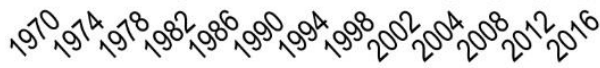

- Total manufacturing - KE services

- Other services
UK share of value added

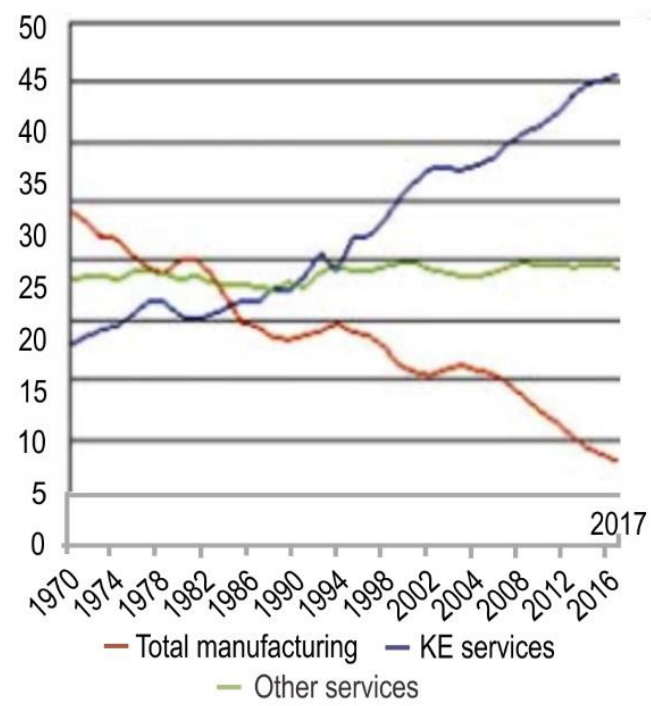

Sources: The Work Foundation estimations from EU KLEMS database and our calculations

Figure 8: The rise of the knowledge worker

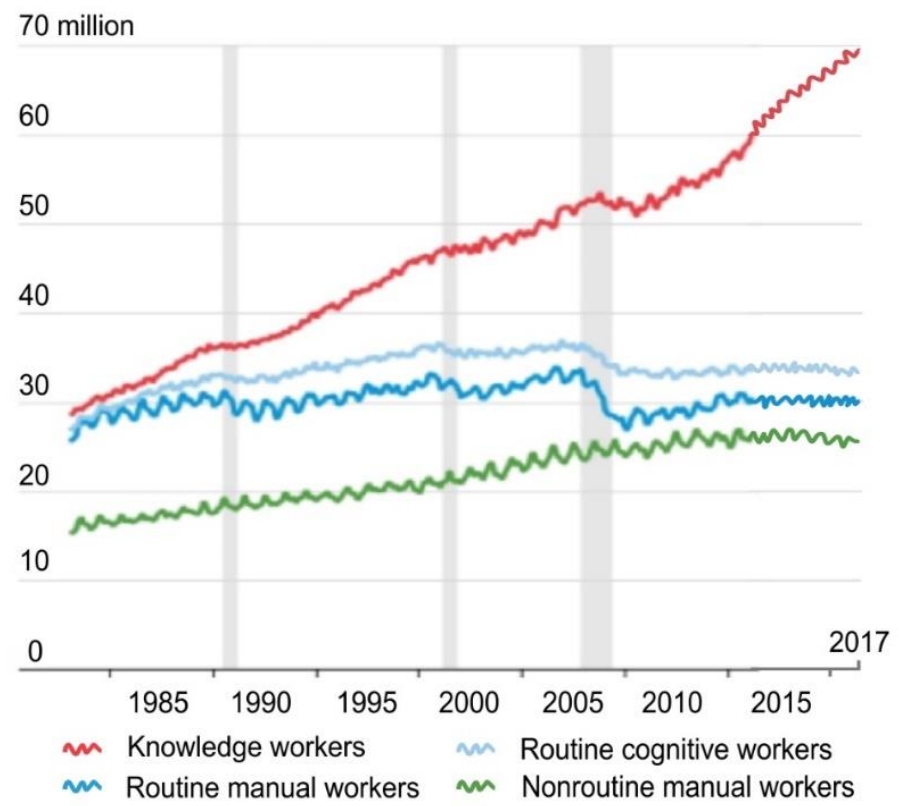

Sources: Labor Department via St. Louis Fed, The Wall Street Journal, and our estimations

\section{Results and discussion}

Using the most relevant additions to the literature, we demonstrate that reputation adjusts the professional market of the knowledge economy by functioning as a particular kind of capital or positive feature for people in a setting constituted of networked and recently mediatized social interplay where participants aim for economic results by improving their social connections, which are accessed and activated by employing an individual's reputational capital. (Gandini, 2016, A) The undertaking in the online realm is performative, being an operation that characterizes a social distinctiveness that connects into value (Selth, 2016), and should be constant, without important discontinuities, generating conspicuousness and 
awareness, and linking unswervingly to offline interplay. The awareness of self-branding routine as the mechanism of articulation of social capital (Hellman \& Majamäki, 2016) is instrumental to the continuation of a reputation economy, because reputation frequently stands for direct confidence building. The construction of a consistent public and social self through performative routines of sociality is a branding undertaking unconnected from the setting up of communitarian connections (Williams et al., 2016), regulated through a curatorial rationale which indicates accuracy. The handling of the material posted and the networking operation are fairly crucial features in the marketability of a digital laborer for the achievement of a reputational capital. (Gandini, 2016, B)

\section{Conclusions}

The current economy is typified by the dispersal of project-based recruitment and the ascent of freelancing: social interplay inherently links with economic valorization throughout networked settings, being moderated through diverse digital devices. In a digitizing labor market, reputation is the aspect distributed by autonomous professional participants in the knowledge economy (Andrei et al., 2016) as a cultural notion of value that converts social interplay into economic results. The actors of such a digital and freelance (Popescu Ljungholm, 2016) knowledge economy contingent on reputational notions of value constitute a novel type of knowledge and creative laborers, who perform as autonomous professionals (Machan \& Chesher, 2016) in such a labor market, employing social media substantially and using their personal links and reputational capital (Mihăilă, 2016, B) to get involved in economic conduct and boost their career, status and positions, having fully internalized the commercial stance (Kantarelis, 2016) of their professional strength as an ideological kind of venture work. (Gandini, 2016, A)

\section{Note}

A version of this article was previously presented at the $17^{\text {th }}$ International Scientific Conference Globalization and Its Socio-Economic Consequences, University of Zilina, 4-5 October 2017.

\section{References}

Ahmed, M. (2016). Bridging the gap between alternative dispute resolution and robust adverse costs orders. Contemporary Readings in Law and Social Justice, 8, 98-126.

Androniceanu, A. (2012). Key issues related to the human resources management nowadays. Proceedings of the $6^{\text {th }}$ International Management Conference: Approaches in Organisational Management. Bucharest, Romania, 221-230.

Andrei, A., Galupa, A., Androniceanu, A. and Georgescu, I.A. (2016). Monetary policy with constant real stock of bonds. Economic Computation and Economic Cybernetics Studies and Research, 50, 101-116.

Androniceanu, A. and Drăgulănescu, I.V. (2016, A). A survey on the buyers' eco-responsibility and the urban white pollution. Environmental Engineering and Management Journal, 15, 481-487.

Androniceanu, A. and Drăgulănescu, I.V. (2016, B). Sustainability of the organizational changes in the context of global economic crisis. Amfiteatru Economic, 14, 365-379.

Androniceanu, A. (2014). Research on management capacity of medical units for addicts to deliver quality services in time of crisis. Revista de Cercetare si Interventie Sociala, 47, 78-104.

Androniceanu, A. (2017). The three-dimensional approach of total quality management, an essential strategic option for business excellence. Amfiteatru Economic, 19, 61-78.

Bauder, H. (2016). Understanding Europe's refugee crisis: A dialectical approach. Geopolitics, History, and International Relations, 8, 64-75. 
Besciu, C.D. and Androniceanu, A. (2017). The link between social inequalities, health system characteristics and R\&D expenditure - worldwide evidence. Romanian Statistical Review, 2, 21-41.

Coyle, D. (2017). Precarious and productive work in the digital economy. National Institute Economic Review, 240(1), R5-R14.

Da Silva, J.C.T. and Baroni Cecato, M.A. (2017). The uberization of the individual relationship of work in the digital age and the Brazilian labor law. Cadernos de Dereito Actual, 7, 257-271.

Friedman, D., Friedman, H.H. and Friedman, L.W. (2016). US healthcare: A system in need of a cure. American Journal of Medical Research, 3, 125-141.

Gandini, A. (2016, A). Digital work: Self-branding and social capital in the freelance knowledge economy. Marketing Theory, 16, 123-141.

Gandini, A. (2016, B). The reputation economy: Understanding knowledge work in digital society. London: Palgrave Macmillan.

Green, A.E. (2017). Implications of technological change and austerity for employability in urban labour markets. Urban Studies, 54(7), 1638-1654.

Hanappi, D., Ryser, V.A. and Bernardi, L. (2016). The role of attitudes towards maternal employment in the relationship between job quality and fertility intentions. Journal of Research in Gender Studies, 6, 192-219.

Hazelkorn, E. (1997). New digital technologies, work practices and cultural production in Ireland. Economic and Social Review, 28(3), 235-239.

Hellman, M. and Majamäki, M. (2016). Ordinary men with extra-ordinary skills? Masculinity constructs among MMORPG-gamers. Journal of Research in Gender Studies, 6, 90-106.

Hurd, H.M. (2016). The innocence of negligence. Contemporary Readings in Law and Social Justice, 8, 48-95.

Kantarelis, D. (2016). A measure of net dependency between the economies of the USA and its major trading partners. Geopolitics, History, and International Relations, 8, 113-145.

Krahe, J. and Campbell, B. (2016). The impact of technology on labor makeup: A study of the green industry. Horttechnology, 26(3), 351-357.

Kirchner, S. (2015). The contours of digital workplaces predictors of ICT usage and the impact on job quality. Kolner Zeitschrift fur Soziologie und Sozialpsychologie, 67(4), 763-791.

Machan, T.R. and Chesher, J. (2016). Government budget crises. Geopolitics, History, and International Relations, 8, 169-176.

Machan, T.R. (2016, A). Rights, values, regulation and health care. American Journal of Medical Research, 3, 115-125.

Machan, T.R. (2016, B). The morality of gregarious egoism. Contemporary Readings in Law and Social Justice, 8, 7-29.

Madsen, E.S. and Wu, Y. (2016). Low R\&D efficiency in large pharmaceutical companies. American Journal of Medical Research, 3, 141-151.

Mihăilă, R. (2016, A). Is the decrease in the gender wage gap the principal driver of the sustained rise in female labor market participation? Journal of Research in Gender Studies, 6, 146-152.

Mihăilă, R. (2016, B). Female labor force participation and gender wage discrimination. Journal of Research in Gender Studies, 6, 262-268.

Mohamed, W.A.W. and 'Ain, N.A. (2017). 21st century skills attainment for women in information and communication technologies in facing globalization. Advanced Science Letters, 22(12), 4557-4560.

Nagel, M. (2016). Gender and the law. Journal of Research in Gender Studies, 6, 107-119.

Popescu Ljungholm, D. (2016). The role of work organizations in the social construction of gender. Journal of Research in Gender Studies, 6, 269-275.

Radic, I.B. (2017). New forms of employment as contemporary challenge for labour law - the case of UBER. Zbornik Pravnog Fakulteta Sveucilista U Rijeci, 38(2), 881-905.

Rickard, A., Wagner, J. and Schull, J. (2017). Observations on the technology and economics of digital emissions. Technology in Society, 48, 28-32.

Siekelova, A., Kliestik, T., Svabova, L., Androniceanu, A. and Schonfeld, J. (2017). Receivables management: The importance of financial indicators in assessing the creditworthiness. Polish Journal of Management Studies, 15, 217-228.

Selth, A. (2016). The road to Mandalay: Orientalism, 'Burma girls' and Western music. Journal of Research in Gender Studies, 6, 159-191.

Vasile, O. and Androniceanu, A. (2016). Dynamics of migration in Romania and management of financing instruments. European Proceedings of Social and Behavioural Sciences. Iasi, Romania, pp. 1059-1067.

Vitalari, N.P. (2016). Prospects for the future of the U.S. healthcare industry: A speculative analysis. American Journal of Medical Research, 3, 7-52. 
Vong, W.T. et al. (2017). Investigating the roles of knowledge management practices in empowering rural youth to bridge the digital divide in rural Sarawak. Journal of Integrated Design \& Process Science, 21(1), 61-79.

Weede, E. (2016). Geopolitics, institutions, and economics: On the rise and decline of civilizations. Geopolitics, History, and International Relations, 8, 177-220.

Williams, J.C., Phillips, K.W. and Hall, E.V. (2016). Tools for change: Boosting the retention of women in the STEM pipeline. Journal of Research in Gender Studies, 6, 11-75. 